\title{
Investigations into the Causes and Control of the Growth Arrestment Phenomenon of Sultana. II. Preliminary Experimental Investigations
}

\author{
D. SAAYMAN
}

Viticultural and Oenological Institute, Private Bag X5026, Stellenbosch, 7600, Republic of South Africa.

Submitted for publication: July 1982

Accepted for publication: January 1983

\begin{abstract}
As a continuation of the investigation into the growth abnormalities, called 'growth arrestment phenomenon' (GAP), which occur extensively in the Sultana vineyards of the Lower Orange River region, field experiments comprising $K$ fertilisation, scheduled irrigation, crop control and specific plant organ and tissue analyses were conducted.

Experimental results showed no response to $K$ fertilisation but a promising response to controlled irrigation. Analyses of various organs revealed a faulty carbohydrate metabolism and high $\mathbf{N}$ concentrations, probably a result of the fertile soil and high temperatures during the growing season, causing vigorous as well as continued shoot growth after harvest. Specific analyses of affected organs and tissues showed black bunches and shiny spots on leaves to be high in $\mathbf{N}$ and $\mathrm{Mn}$ and low in $\mathrm{K}$.

It is postulated that amongst the major factors causing GAP are the specific climatic and soil conditions which cause poor accumulation of reserves and high $\mathbf{N}$ contents. The mechanism by which GAP is caused and practical measures to combat this phenomenon merit urgent further studies.
\end{abstract}

The environmental conditions, the occurence of the growth arrestment phenomenon (GAP) amongst the Vitis vinifera L. cv. Sultanina vineyards of the Lower Orange River region, the symptons associated with GAP and the analytical characteristics of affected plant organs and associated soil, have already been reported (Saayman, 1983). Preliminary results indicated that $\mathrm{K}$ nutrition and irrigation practices may be factors contributing to GAP. The phenomenon of vines having a very high yield in one year, followed by a very low yield as well as sparse budding and retarded growth the following year, led to investigations into the possible contribution of overcropping to the occurrence of GAP, and the efficiency of reserve hydrolyses in spring or the general adequacy of reserves.

\section{MATERIALS AND METHODS}

Two co-operative field experiments were initiated. In Experiment I the following treatments, which were replicated in GAP classified vineyards on eight farms, were evaluated:

A: Control, no treatment

B: Production control -15 bunches per vine

C: $\mathrm{K}$ fertilisation - 3,0 t $\mathrm{K}_{2} \mathrm{SO}_{4} /$ ha plus five $0,5 \%$

$\mathrm{K}_{2} \mathrm{SO}_{4}$ weekly foliar sprays between bud burst and flowering, followed by fortnightly $3 \% \mathrm{~K}_{2} \mathrm{SO}_{4}$ sprays after harvest until leaf drop

$\mathrm{D}$ : $\mathrm{K}$ fertilisation and foliar sprays as in $\mathrm{C}$, plus production control as in $\mathrm{B}$.

Potassium fertilisation was done by injecting saturated $\mathrm{K}_{2} \mathrm{SO}_{4}$ solution into the soil by means of fumigant pumps in a circular pattern with a radius of $c .1,5 \mathrm{~m}$ around each vine. Treatments commenced during 1973 and each plot consisted of four Sultana vines with a known history of GAP. Plots were randomly selected in existing vineyards, and those which received $\mathrm{K}$ fertilisation were situated at least $5 \mathrm{~m}$ from other plots. In the case of four farms (replicates), irrigation schedules based on the water holding capacity of the soil, class A-pan evaporation data, a 0,6 crop factor and a $50 \%$ available moisture depletion of the soil, amounting to $c .12$ flood irrigations of $c .150 \mathrm{~mm}$ each during the growing season (Sept.-March), were prescribed. The remaining four producers continued their normal irrigation practices which were generally between 7 and 8 irrigations of $150-250 \mathrm{~mm}$ each during the growing season.

Soil samples were taken after the application of $\mathrm{K}$, and samples of bearer canes, new shoot growth and leaves were taken at flowering stage and analysed for the major elements using standard VORI methods. Shoot and crop mass were determined during the initial three seasons, but discontinued because of unsatisfactory control over irrigation applications, the lack of success in regulating production and dwindling producers' interest. A final evaluation of GAP affliction was done during October, 1979.

Parallel to this investigation, a second trial, Exp. II, was conducted in which eight-vine plots which were monitored during the general survey (Saayman, 1983) were selected in order to have ten plots representing GAP vineyards and another ten plots of normal vines. These plots were sampled as follows:

- Dormant shoots sampled at pruning

- Canes sampled just before bud burst

- Canes sampled just after bud burst

- Canes sampled during the growth arrestment stage (October).

These samples were analysed for starch, sugar and arginine, using standard VORI procedures.

In addition to these two experiments, specific case studies were also carried out where good examples of pronounced GAP symptoms were encountered, and plant material were sampled for macro- and micro element analyses.

\section{RESULTS AND DISCUSSION}

K-fertilisation and irrigation effects: The effect of intensive $\mathrm{K}$ fertilisation on the soil as investigated in Experiment $\mathrm{I}$, is shown in Table 1. It is clear that the massive 
$\mathrm{K}$ applications highly significantly increased the rather low $\mathrm{K}$ content of the soil concerned $(0,42 \mathrm{me} \%)$ to a much higher level $(1,13 \mathrm{me} \%)$ than the $0,52 \mathrm{me} \%$ in the topsoil of soils found to be associated with GAP vines (Saayman, 1983), and also significantly increased the K content of canes and shoots (Table 2). However, according to the relevant data in Table $3, \mathrm{~K}$ fertilisation had no significant effect on vine performance, nor on the incidence of GAP. It would appear, therefore, that $\mathrm{K}$ fertilisation alone cannot alleviate GAP and that the low $\mathrm{K}$ content of plant material usually associated with GAP, is the result of other factors and not the cause of GAP.

TABLE 1

Effect of intensive $\mathrm{K}$ fertilisation on the mean chemical properties of GAP prone soil

\begin{tabular}{|c|c|c|c|c|c|c|c|}
\hline \multirow[t]{2}{*}{$\begin{array}{l}\text { Treat- } \\
\text { ment }\end{array}$} & \multirow[t]{2}{*}{$\begin{array}{l}\mathrm{pH} \\
(\mathrm{KC} 1)\end{array}$} & \multirow{2}{*}{$\begin{array}{l}\text { Resis- } \\
\text { tance } \\
\text { (ohm) }\end{array}$} & \multirow[t]{2}{*}{$\begin{array}{l}\mathrm{P}^{1)} \\
(\mathrm{ppm})\end{array}$} & \multicolumn{4}{|c|}{$\begin{array}{l}\text { Total exchangeable } \\
\text { cations }(\mathrm{me} \%)\end{array}$} \\
\hline & & & & $\mathrm{K}$ & $\mathrm{Na}$ & $\mathrm{Ca}$ & $\mathrm{Mg}$ \\
\hline A: & 6,71 & 718 & 72 & 0,42 & 0,39 & 19,0 & 5,9 \\
\hline B: & 6,65 & 562 & 66 & 1,13 & 0,38 & 18,2 & 5,8 \\
\hline $\begin{array}{l}\text { Signi- } \\
\text { ficance }\end{array}$ & ns & $*$ & ns & $* *$ & ns & ns & ns \\
\hline
\end{tabular}

1) $1 \%$ Citric acid extractable

A: Control, no $\mathrm{K}$

B: $3 \mathrm{t} \mathrm{K}_{2} \mathrm{SO}_{4} / \mathrm{ha}+\mathrm{K}_{2} \mathrm{SO}_{4}$ foliar sprays

** Highly significant $(\mathrm{P} \leq 0,01)$; *Significant $(\mathrm{P} \leq 0,05)$;

$\mathrm{ns}=$ not significant .

The clay fraction of the soil of the Lower Orange River region was shown to contain 2:1 mixed layer and mica-like clay minerals so that $\mathrm{K}$ fixation can be expected. It has already been shown that lower $\mathrm{K}$ contents and heavier texture are associated with GAP soils (Saayman, 1983) suggesting stronger $\mathrm{K}$ fixation. However, a highly significant negative curvi-linear relationship between the clay content of soils and the cation exchange capacity (CEC) of the clay present in the soil was found (Fig. 1). This indicated a more advanced degree of weathering of clay minerals in heavier textured soil and, therefore, a relatively lower $\mathrm{K}$ fixing capacity. The high CEC/100 g clay values obtained indicate that the silt and even sand fractions contain micalike material which are contributing to the CEC measured.
TABLE 2

The effect of $\mathrm{K}$ fertilisation and foliar sprays on the macro nutrient content of organs of GAP afflicted Sultana during flowering Lower Orange River region, 1978/79

\begin{tabular}{|c|c|c|c|c|c|}
\hline \multirow[t]{2}{*}{ Element } & \multirow[t]{2}{*}{ Treatment } & \multicolumn{4}{|c|}{ Organ } \\
\hline & & Canes & $\begin{array}{l}\text { Green } \\
\text { shoots }\end{array}$ & $\begin{array}{l}\text { Leaves \& } \\
\text { petioles }\end{array}$ & $\begin{array}{l}\text { Flower } \\
\text { clusters }\end{array}$ \\
\hline \multirow[t]{3}{*}{$\mathrm{N} \%$} & A & 0,48 & 0,87 & 3,03 & 1,78 \\
\hline & B & 0,50 & 1,14 & 3,06 & 1,93 \\
\hline & Significance & ns & $*$ & ns & ns \\
\hline \multirow[t]{3}{*}{$\mathrm{P} \%$} & A & 0,10 & 0,20 & 0,22 & 0,23 \\
\hline & B & 0,13 & 0,26 & 0,25 & 0,26 \\
\hline & Significance & ns & ns & ns & ns \\
\hline \multirow[t]{3}{*}{$\mathrm{K} \%$} & A & 0,53 & 1,03 & 0,91 & 1,42 \\
\hline & $\mathrm{B}$ & 0,63 & 1,43 & 1,06 & 1,53 \\
\hline & Significance & $*$ & $*$ & ns & ns \\
\hline \multirow[t]{3}{*}{$\mathrm{Na} \%$} & $\mathbf{A}$ & 0,028 & 0,11 & 0,037 & 0,024 \\
\hline & B & 0,033 & 0,06 & 0,028 & 0,024 \\
\hline & Significance & ns & ns & ns & ns \\
\hline \multirow[t]{3}{*}{$\mathrm{Ca} \%$} & A & 0,46 & 0,51 & 1,78 & 0,37 \\
\hline & B & 0,46 & 0,53 & 1,62 & 0,40 \\
\hline & Significance & ns & ns & ns & ns \\
\hline \multirow[t]{3}{*}{$\mathrm{Mg} \%$} & A & 0,110 & 0,205 & 1,78 & 0,37 \\
\hline & B & 0,099 & 0,196 & 1,62 & 0,40 \\
\hline & Significance & ns & ns & ns & ns \\
\hline
\end{tabular}

A: Control, no $\mathrm{K}$

B: $3 \mathrm{t} \mathrm{K}_{2} \mathrm{SO}_{4} / \mathrm{ha}+\mathrm{K}_{2} \mathrm{SO}_{4}$ foliar sprays

* Significant $(\mathrm{P} \leq 0,05)$

$\mathrm{ns}=$ not significant

Scheduled irrigation had a highly significant initial positive effect on both shoot mass and production but did not improve GAP (Table 3), probably because of a lack of sustained co-operation from the producers in adhering to the desired schedules. However, there is little doubt that irrigation is an important contributing factor to the incidence of GAP. This finding has been confirmed by observations in practice that GAP could easily be induced by allowing the soil to dry out during the dormancy period. This is also in accordance with the indications obtained during the preliminary survey

TABLE 3

The effect of $\mathrm{K}$ fertilisation and foliar sprays, as well as scheduled irrigation on the performance of Sultana vines and the incidence of GAP, Lower Orange River region

\begin{tabular}{|c|c|c|c|c|c|c|c|c|}
\hline \multirow[b]{2}{*}{ Treatment } & \multicolumn{3}{|c|}{ Shoot mass (kg/plot) } & \multicolumn{3}{|c|}{ Crop mass (t/ha) } & \multicolumn{2}{|c|}{ GAP index 1 ) } \\
\hline & $1973 / 74$ & $1974 / 75$ & $1975 / 76$ & $1973 / 74$ & $1974 / 75$ & $1975 / 76$ & $1975 / 76$ & $1978 / 79$ \\
\hline A: & 5,1 & 4,5 & 3,3 & 9,4 & 11,4 & 16,8 & 11,7 & 10,6 \\
\hline B: & 4,7 & 3,9 & 3,0 & 11,3 & 16,0 & 19,6 & 11,1 & 10,7 \\
\hline Significance & ns & ns & ns & ns & $\mathrm{ns}$ & ns & ns & ns \\
\hline C: & 3,8 & 2,2 & 3,0 & 6,9 & 15,0 & 15,1 & 11,9 & 9,9 \\
\hline $\mathrm{D}:$ & 6,1 & 6,3 & 3,4 & 13,6 & 12,6 & 21,3 & 11,0 & 11,6 \\
\hline Significance & $* *$ & $* *$ & ns & $* *$ & ns & ns & ns & $* *$ \\
\hline
\end{tabular}

1) Index was based on the presence of defined symptoms, resulting in a 7-21 scale, high values indicating severe GAP

A: Control, no $\mathrm{K}$

B: $3 \mathrm{t} \mathrm{K}_{2} \mathrm{SO}_{4} / \mathrm{ha}+\mathrm{K}_{2} \mathrm{SO}_{4}$ foliar sprays

$\mathrm{C}$ : Control, farmer's irrigation

D: Scheduled irrigation

* Significant $(\mathrm{P} \leq 0,05) ; * *$ Highly significant $(\mathrm{P} \leq 0,01) ; \mathrm{ns}=$ not significant 


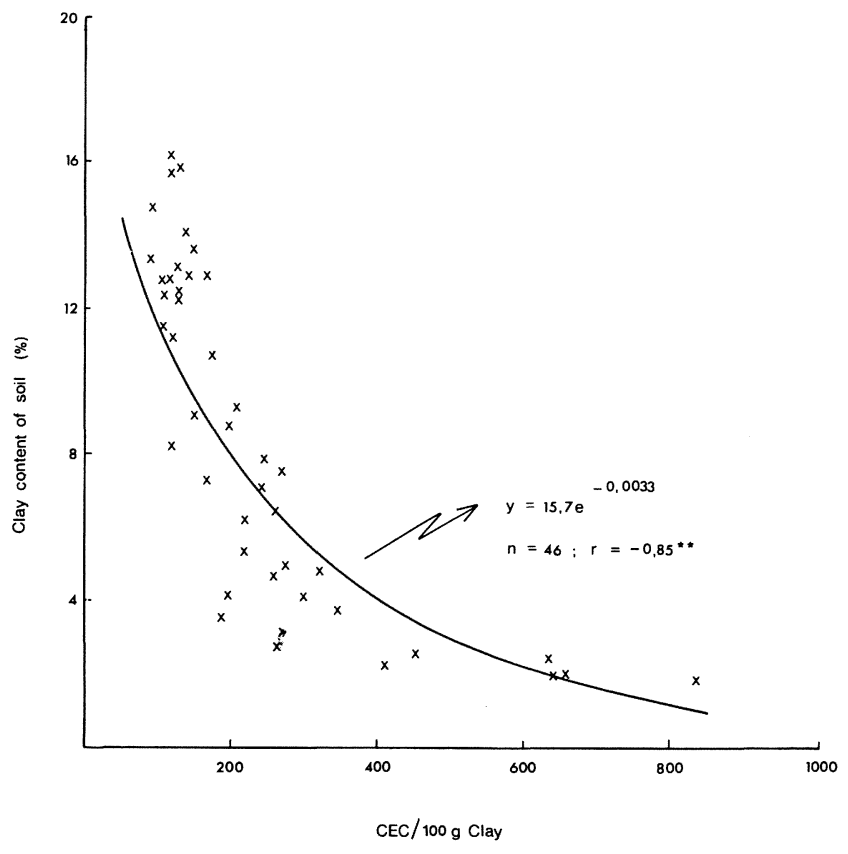

Fig. 1

The relationship between the clay content of Lower Orange River region soils and the CEC of the clay present in the soil.

(Saayman, 1983). The reason for this is still not understood but may be the result of higher $\mathrm{Na}$ concentrations in dry soil, physical damage to roots due to deep cracks forming in the dry soil or larger temperature fluctuations in dry soil compared to those in moist soil. All these factors may contribute to poor root activity during the critical budding to flowering stage.

Carbohydrate and nitrogen reserves: The analytical results obtained in connection with Experiment II on selected GAP and normal vines, are shown in Table 4. Healthy canes contained significantly to highly significantly higher concentrations of starch before budding than GAP canes. During the growth arrestment period (flowering), the normal canes tended to have lower starch concentrations than GAP canes, but again showed a marked tendency towards a higher starch content than GAP canes at pruning time. Kliewer (1978) also found highly significant lower total carbohydrate concentrations in canes and roots of GAP vines. These results point to an inability of GAP vines to synthesise and accumulate sufficient carbohydrate reserves. The pattern observed concerning the sugar content of canes, showed a tendency towards an accumulation of sugar during dormancy and a significantly slower utilisation of sugar after budding in the case of GAP vines. During the GAP period, normal canes tended to have the highest sugar content, indicating either a more rapid synthesis of sugars due to larger active leaf surface, or to a more rapid hydrolysis of starch to sugar, as indicated by a lower starch content in normal canes in comparison to that in GAP canes at this stage (Table 4).

TABLE 4

Sugar, starch and arginine content of Sultana canes as affected by GAP - Lower Orange River region, 1973/74

\begin{tabular}{|c|c|c|c|c|c|c|c|}
\hline Growth stage & $\begin{array}{l}\text { Vine } \\
\text { condition }\end{array}$ & $\begin{array}{l}\text { Sugar } \\
(\%)\end{array}$ & $\begin{array}{l}\text { Signifi- } \\
\text { cance }\end{array}$ & $\begin{array}{l}\text { Starch } \\
(\%)\end{array}$ & $\begin{array}{l}\text { Signifi- } \\
\text { cance }\end{array}$ & $\begin{array}{l}\text { Arginine } \\
(\mathrm{ppm})\end{array}$ & $\begin{array}{l}\text { Signifi- } \\
\text { cance }\end{array}$ \\
\hline Winter dormancy (pruning) & $\begin{array}{l}\text { GAP } \\
\text { Normal } \\
\end{array}$ & $\begin{array}{l}4,05 \\
3,72 \\
\end{array}$ & ns & $\begin{array}{l}3,05 \\
3,44 \\
\end{array}$ & ns & $\begin{array}{l}3289 \\
4524 \\
\end{array}$ & $*$ \\
\hline Before budding & $\begin{array}{l}\text { GAP } \\
\text { Normal }\end{array}$ & $\begin{array}{l}2,67 \\
2,87 \\
\end{array}$ & ns & $\begin{array}{l}4,99 \\
6,41 \\
\end{array}$ & $*$ & $\begin{array}{l}5510 \\
6777 \\
\end{array}$ & ns \\
\hline After budding & $\begin{array}{l}\text { GAP } \\
\text { Normal }\end{array}$ & $\begin{array}{l}1,86 \\
0,77 \\
\end{array}$ & $* *$ & $\begin{array}{l}4,61 \\
5,67 \\
\end{array}$ & $\mathrm{~ns}$ & $\begin{array}{l}6170 \\
5680 \\
\end{array}$ & ns \\
\hline GAP period (flowering) & $\begin{array}{l}\text { GAP } \\
\text { Normal } \\
\end{array}$ & $\begin{array}{l}1,12 \\
2,09 \\
\end{array}$ & ns & $\begin{array}{l}3,29 \\
2,45 \\
\end{array}$ & ns & $\begin{array}{l}1381 \\
1000 \\
\end{array}$ & ns \\
\hline Winter dormancy (pruning) & $\begin{array}{l}\text { GAP } \\
\text { Normal }\end{array}$ & $\begin{array}{l}4,24 \\
5,17 \\
\end{array}$ & $\mathrm{~ns}$ & $\begin{array}{l}1,46 \\
3,24\end{array}$ & $\mathrm{~ns}$ & $\begin{array}{l}5096 \\
4602 \\
\end{array}$ & $\mathrm{~ns}$ \\
\hline Before budding & $\begin{array}{l}\text { GAP } \\
\text { Normal }\end{array}$ & $\begin{array}{l}4,56 \\
3,09\end{array}$ & ns & $\begin{array}{l}1,61 \\
4,53\end{array}$ & $* *$ & $\begin{array}{l}5412 \\
6817\end{array}$ & ns \\
\hline
\end{tabular}

** Highly significant $(\mathrm{P} \leq 0,01) . \quad *$ Significant $(\mathrm{P} \leq 0,05) . \quad$ ns $=$ not significant.

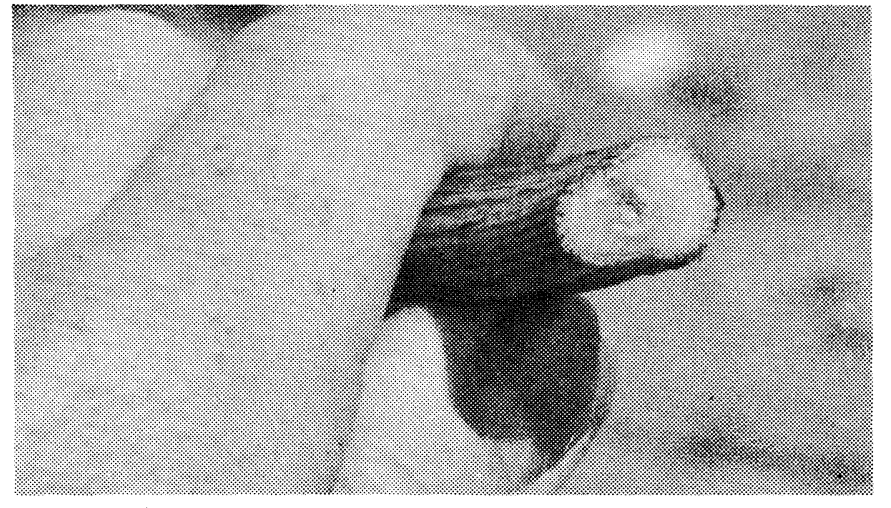

(a)

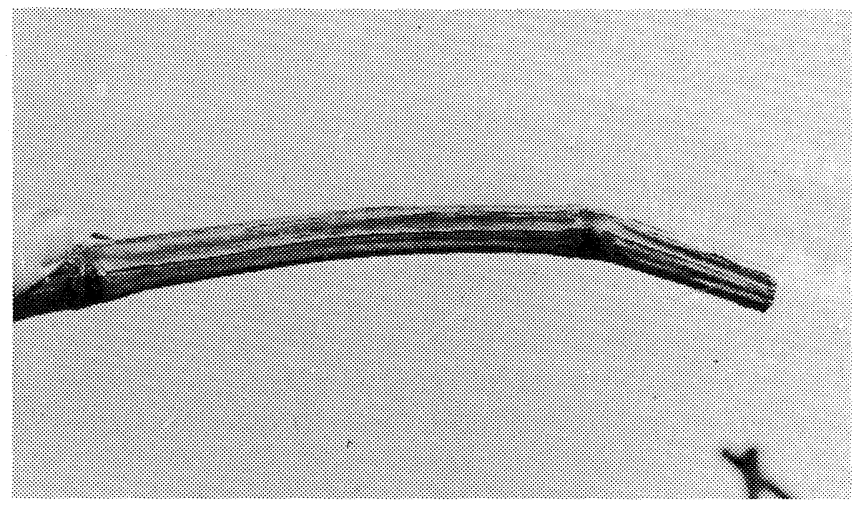

(b)

PLATE 1

Flattened shoots (a) with long internodes (b), resulting from vigorous shoot growth of Sultana 
With regard to the arginine content of canes, there seems to be no clear or consistent pattern. Kliewer (1978) found canes of both GAP and normal vines to contain 2 to 10 times more arginine after budding than is considered normal for Sultana vines in California.

These results indicate an unbalanced carbohydrate/ nitrogen status in GAP vines, as was also postulated by Kliewer (1978). This is probably related to the general high vigour of Sultana in this region, often resulting in flattened shoots with long internodes (Plate 1), as well as a tendency to continue growing vigorously after harvest and attaining lengths of more than $10 \mathrm{~m}$, until the first autumn frost kills all leaves suddenly (Plate 2), apparently before proper reserve translocation could take place. Terblanche (1974) also expressed the opinion that the tendency of Sultana in the Lower Orange River area to continue growing after harvest, leads to low reserves and subsequent poor budding and fruit set. $\mathrm{He}$ postulated that flower shatter was not connected to black bunch and shiny spot symptoms, but was the result of vigorous shoot growth after the initial growth arrestment period.

During October 1979, typical GAP afflicted vines as well as adjacent vines appearing normal, were again sampled and analysed, and the results for $\mathrm{N}$, arginine, $\mathrm{K}$ and $\mathrm{Na}$ are shown in Table 5. These data point to a build-up of total $\mathrm{N}$ in shoots, canes, trunk, fine roots and flower clusters of GAP vines, with arginine following a rather similar pattern. No clear pattern concerning the $\mathrm{K}$ content was obtained, whereas $\mathrm{Na}$ contents appear to be similar for both GAP affected and healthy vines.

TABLE 5

Nitrogen, arginine, potassium and sodium content of organs from GAP afflicted and normal vines, Oct. 1979, Lower Orange River region.

\begin{tabular}{|c|c|c|c|c|c|}
\hline \multirow{2}{*}{$\begin{array}{l}\text { Component } \\
\text { analysed }\end{array}$} & \multirow{2}{*}{$\begin{array}{l}\text { Vine } \\
\text { condition }\end{array}$} & \multicolumn{4}{|c|}{ Element } \\
\hline & & $\begin{array}{l}\mathrm{N} \\
(\%)\end{array}$ & $\begin{array}{l}\text { Arginine } \\
\text { (ppm) }\end{array}$ & $\begin{array}{l}\mathrm{K} \\
(\%)\end{array}$ & $\begin{array}{l}\mathrm{Na} \\
(\%)\end{array}$ \\
\hline \multirow[t]{2}{*}{ Leaves \& petioles } & GAP & 3,36 & 1393 & 0,93 & 0,015 \\
\hline & Normal & 3,70 & 1436 & 1,13 & 0,037 \\
\hline \multirow[t]{2}{*}{ Flower clusters } & GAP & 3,51 & 655 & 1,76 & 0,013 \\
\hline & Normal & 3,13 & 746 & 1,76 & 0,017 \\
\hline \multirow[t]{2}{*}{ Green shoots } & GAP & 2,27 & 489 & 1,13 & 0,059 \\
\hline & Normal & 1,49 & 600 & 0,96 & 0,061 \\
\hline \multirow[t]{2}{*}{ Canes } & GAP & 0,88 & 7693 & 0,42 & 0,055 \\
\hline & Normal & 0,60 & 2097 & 0,51 & 0,056 \\
\hline \multirow{2}{*}{$\begin{array}{l}\text { Two year old } \\
\text { wood } \\
\end{array}$} & GAP & 0,76 & 7147 & 0,37 & 0,026 \\
\hline & Normal & 0,63 & 5134 & 0,39 & 0,022 \\
\hline \multirow[t]{2}{*}{ Trunk } & GAP & 0,50 & 3739 & 0,30 & 0,030 \\
\hline & Normal & 0,35 & 1864 & 0,31 & 0,034 \\
\hline \multirow{2}{*}{$\begin{array}{l}\text { Fine Roots } \\
(<2 \mathrm{~mm} \emptyset)\end{array}$} & GAP & 3,39 & 51824 & 0,37 & 0,18 \\
\hline & Normal & 2,86 & $421 \% 0$ & 0,32 & 0,23 \\
\hline \multirow{2}{*}{$\begin{array}{l}\text { Thick Roots } \\
(>2 \mathrm{~mm} \emptyset)\end{array}$} & GAP & 3,27 & 58812 & 0,23 & 0,11 \\
\hline & Normal & 3,23 & 60403 & 0,25 & 0,10 \\
\hline
\end{tabular}

Organic material in soils: Analyses of composite soil samples obtained from all samples collected during the intensive survey, showed that soils associated with GAP vines tended to be slightly richer in organic material $(\mathrm{OM})$, total nitrogen and nitrate- $\mathrm{N}$ in the topsoil (Table 6). The abnormally high $\mathrm{C} / \mathrm{N}$ ratio in the soil indicates either inadequate recovery of $\mathrm{N}$ during the analyses procedure, as suggested by the relatively low $\mathrm{N}$ values obtained, or is due to conditions totally unfavourable to microbial activity (Champagnol, 1980). Values of 790 $-1100 \mathrm{ppm} \mathrm{N}$ are associated with normally cultivated soil, and values of 1300 - $1800 \mathrm{ppm}$ with soils planted to alfalfa or which received heavy applications of manure. Nitrate-N values of $5-7 \mathrm{ppm}$ seems to be normal for conventionally tilled soils, but reach values of $9-18$ ppm in the case of manured soil (Fox \& Piekielek, 1978). Although Agenbach (1975) found low nitrate concentrations in selected soils from the Lower Orange River region, the nitrification ability of these soils were shown to be normal, and that for the largest part of the season GAP classified soil contained highly significantly more nitrate that "normal" soils (Fig. 2). While low nitrate $\mathrm{N}$ values could $\mathrm{bm}$ ascribed to a leaching effect of the frequent flood irrigations, the reason for the low total $\mathrm{N}$ values obtained for these soils remains unknown.

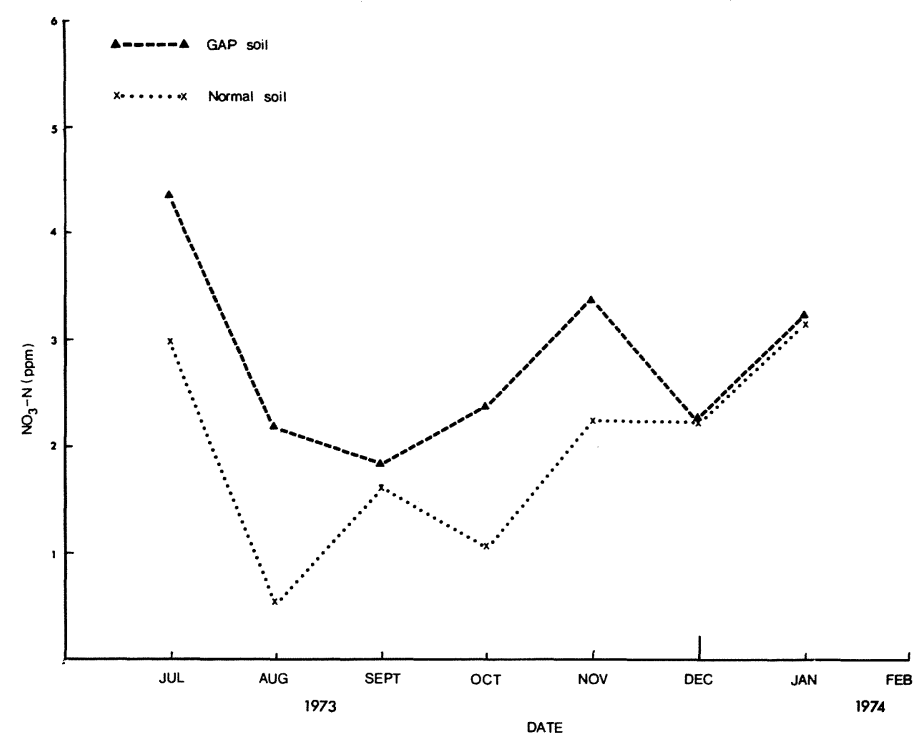

Fig. 2

Nitrate-N content of GAP classified and normal soil - Lower Orange River region. (After Agenbach, 1975).

Specific tissue analyses: An independent investigation by Terblanche (1974) revealed that apart from low K concentrations, toxic concentrations of $\mathrm{Na}$ were present in leaf blades, petioles and peduncles of GAP classified vines (Table 7). He suggested that the black bunch symptom is related to shiny spot leaves, and that the low $\mathrm{K}$ content of affected material was due to the suppression 


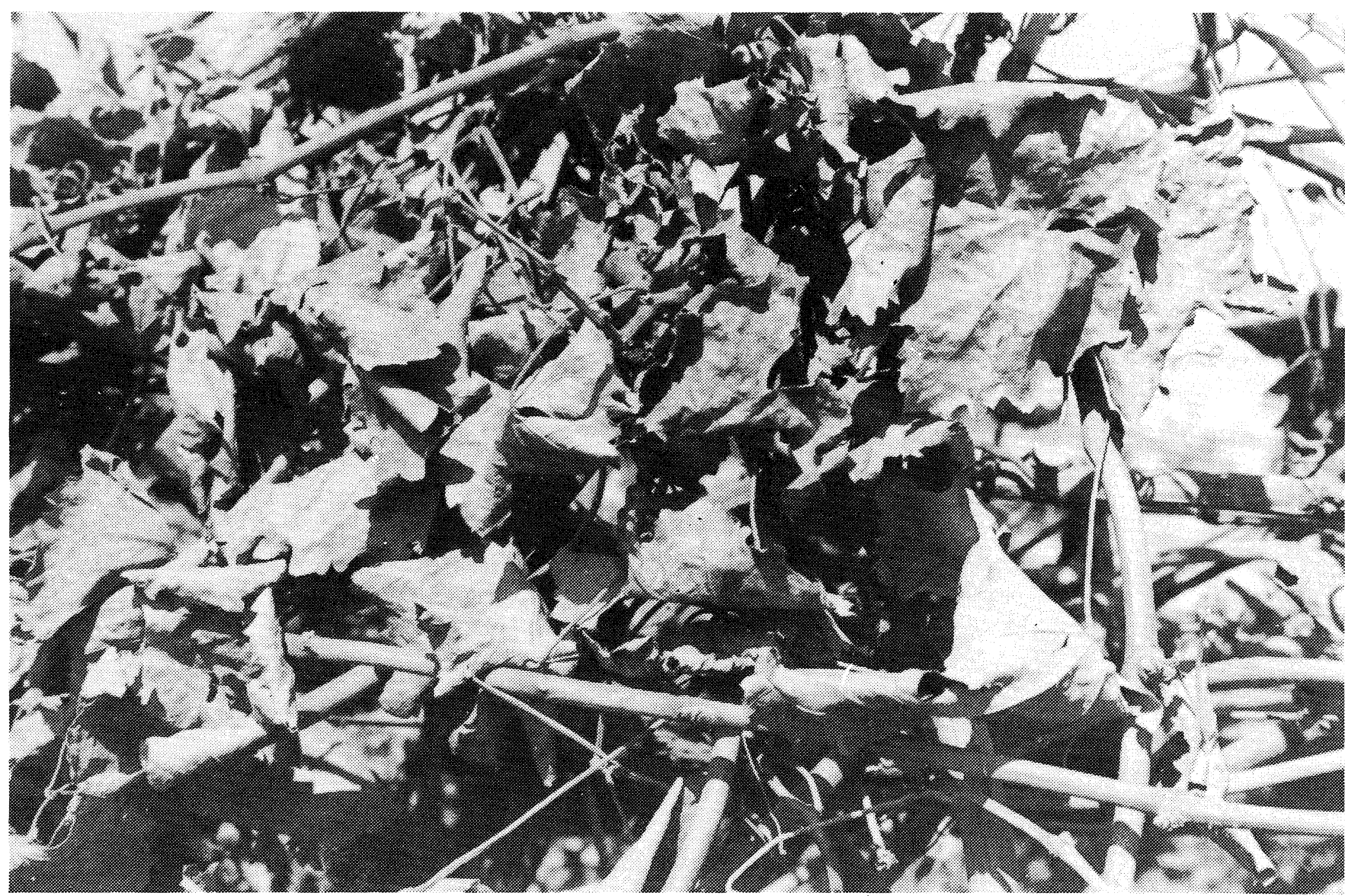

(a)

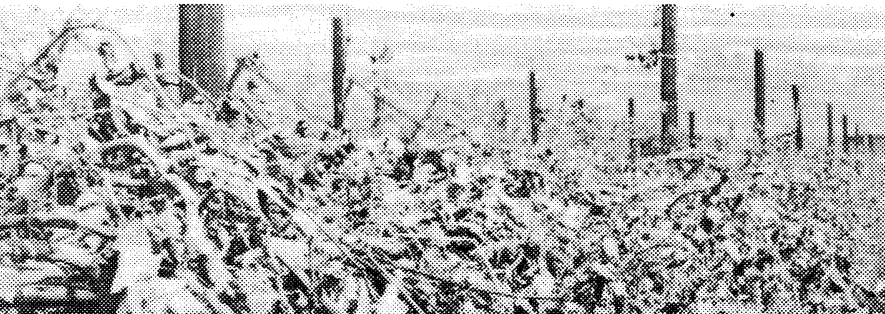
-

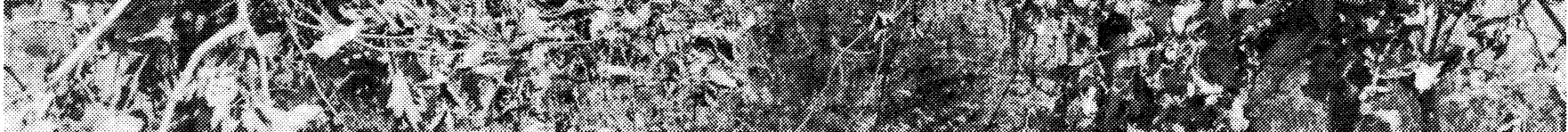

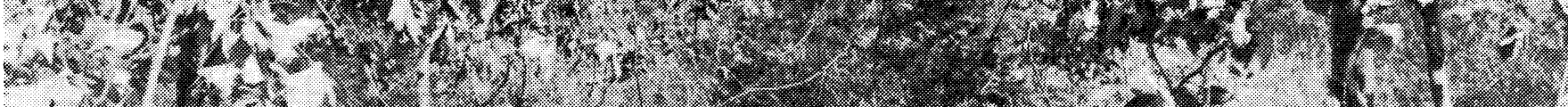

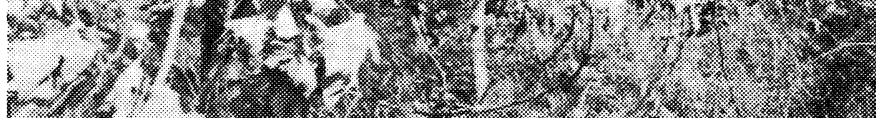

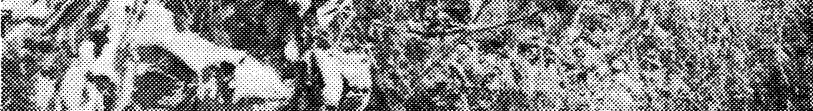

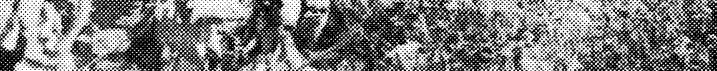

c.

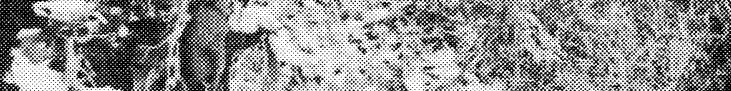
(2)

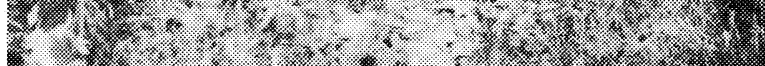
F. 20:

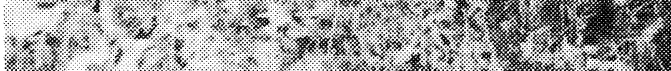

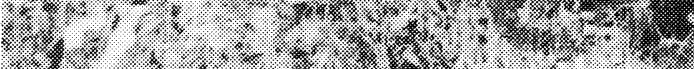

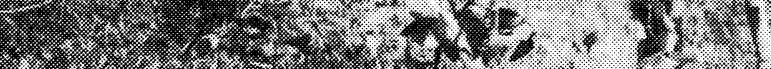

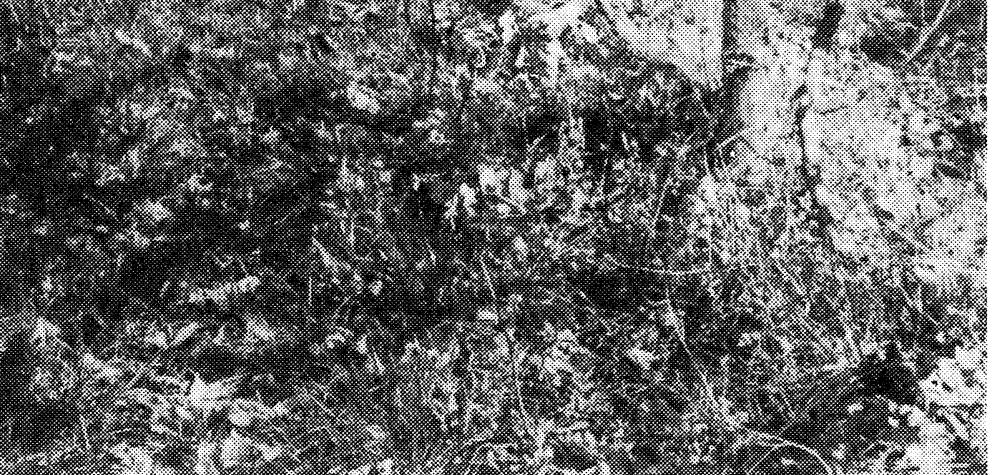
(b)

(a) Green leaves killed in an active stage by frost (b), preventing normal leaf abscission. 
TABLE 6

Organic carbon, total nitrogen and nitrate- $\mathrm{N}$ content and mechanical composition of soils associated with normal and GAP Sultana vines - Lower Orange River region. ${ }^{1)}$

\begin{tabular}{|c|c|c|c|c|c|c|c|c|c|}
\hline Category & $\begin{array}{l}\text { Horison } \\
(\mathrm{cm})\end{array}$ & $\begin{array}{l}\text { Clay } \\
(\%)\end{array}$ & $\begin{array}{l}\text { Silt } \\
(\%)\end{array}$ & $\begin{array}{l}\text { Sand } \\
(\%)\end{array}$ & $\begin{array}{l}\text { Carbon } \\
(\%)\end{array}$ & $\begin{array}{l}\mathrm{OM}^{2)} \\
(\%)\end{array}$ & $\begin{array}{l}\text { Total N } \\
(\mathrm{ppm})\end{array}$ & $\begin{array}{l}\text { Nitrate-N } \\
(\mathrm{ppm})\end{array}$ & $\begin{array}{l}\mathrm{C} / \mathrm{N} \\
\text { ratio }\end{array}$ \\
\hline Normal & $\begin{array}{r}0 / 30 \\
30 / 60\end{array}$ & $\begin{array}{r}13,0 \\
6,4\end{array}$ & $\begin{array}{r}11,3 \\
5,5\end{array}$ & $\begin{array}{l}76,8 \\
87,4\end{array}$ & $\begin{array}{l}1,36 \\
0,55\end{array}$ & $\begin{array}{l}2,34 \\
0,95\end{array}$ & $\begin{array}{l}620 \\
250 \\
\end{array}$ & $\begin{array}{l}3,4 \\
2,9 \\
\end{array}$ & $\begin{array}{l}22 \\
22\end{array}$ \\
\hline$\overline{\text { GAP }}$ & $\begin{array}{r}0 / 30 \\
30 / 60\end{array}$ & $\begin{array}{r}15,1 \\
6,1\end{array}$ & $\begin{array}{r}13,0 \\
6,2\end{array}$ & $\begin{array}{l}74,6 \\
86,8\end{array}$ & $\begin{array}{l}1,42 \\
0,49\end{array}$ & $\begin{array}{l}2,45 \\
0,84\end{array}$ & $\begin{array}{l}650 \\
260\end{array}$ & $\begin{array}{l}9,0 \\
3,3\end{array}$ & $\begin{array}{l}22 \\
19\end{array}$ \\
\hline
\end{tabular}

1) Analyses were done on composite samples obtained from $c .100$ individual soil samples collected during an intensive survey of the whole region.

2) Organic material; a carbon content of humus for cultivated soil of $58 \%$ was accepted (Champagnol, 1980).

TABLE 7

Nutrient content of leaf blades, petioles and peduncles of normal and GAP vines ${ }^{1)}$, Lower Orange River region.

\begin{tabular}{|c|c|c|c|c|c|c|c|c|}
\hline \multirow{2}{*}{ Organ/Tissue } & \multirow{2}{*}{$\begin{array}{l}\text { Vine } \\
\text { condition }\end{array}$} & \multicolumn{6}{|c|}{ Element } & \multirow{2}{*}{$\mathrm{K} / \mathrm{Na}$} \\
\hline & & $\begin{array}{l}\mathrm{N} \\
(\%)\end{array}$ & $\begin{array}{l}\mathrm{P} \\
(\%)\end{array}$ & $\begin{array}{l}\mathrm{K} \\
(\%)\end{array}$ & $\begin{array}{l}\mathrm{Ca} \\
(\%)\end{array}$ & $\begin{array}{l}\mathrm{Mg} \\
(\%)\end{array}$ & $\begin{array}{l}\mathrm{Na} \\
(\%)\end{array}$ & \\
\hline \multirow[t]{2}{*}{ Leaf blades } & Normal & 4,37 & 0,47 & 1,09 & 1,46 & 0,32 & 0,05 & 21,8 \\
\hline & GAP & 3,88 & 0,34 & 0,74 & 1,99 & 0,43 & 0,40 & 1,9 \\
\hline \multirow[t]{2}{*}{ Petioles } & Normal & 1,66 & 0,70 & 3,36 & 0,97 & 0,36 & 0,04 & 84,0 \\
\hline & GAP & 2,33 & 0,30 & 0,70 & 1,32 & 0,85 & 1,01 & 0,7 \\
\hline \multirow[t]{2}{*}{ Peduncles } & Normal & 3,54 & 0,54 & 2,76 & 0,58 & 0,15 & 0,02 & 138 \\
\hline & GAP & 4,60 & 0,41 & 1,01 & 0,62 & 0,26 & 0,65 & 1,6 \\
\hline \multirow[t]{2}{*}{ Leaf tissue } & Normal & 3,39 & 0,22 & 0,70 & 2,70 & 0,60 & 0,14 & 5,0 \\
\hline & Shiny spot & 3,08 & 0,22 & 0,78 & 2,52 & 0,51 & 0,28 & 2,8 \\
\hline
\end{tabular}

1) After Terblanche (1974)

of $\mathrm{K}$ uptake by $\mathrm{Na}$. Although not mentioned in his report, a high $\mathrm{N}$ content of GAP petioles and peduncles is also evident from his data.

The analysis results of leaf and flower cluster tissue sampled on the Upington experimental farm from vines showing typical GAP symptoms and from adjacent normal appearing vines, as well as from vines showing marginal yellowing of leaves, resembling K-deficiency, and curled leaf symptoms, are shown in Table 8. A tendency towards $\mathrm{N}$ build-up, especially in petioles of shiny spot and curled leaves, but also in petioles of leaves showing marginal yellowing, is again evident.

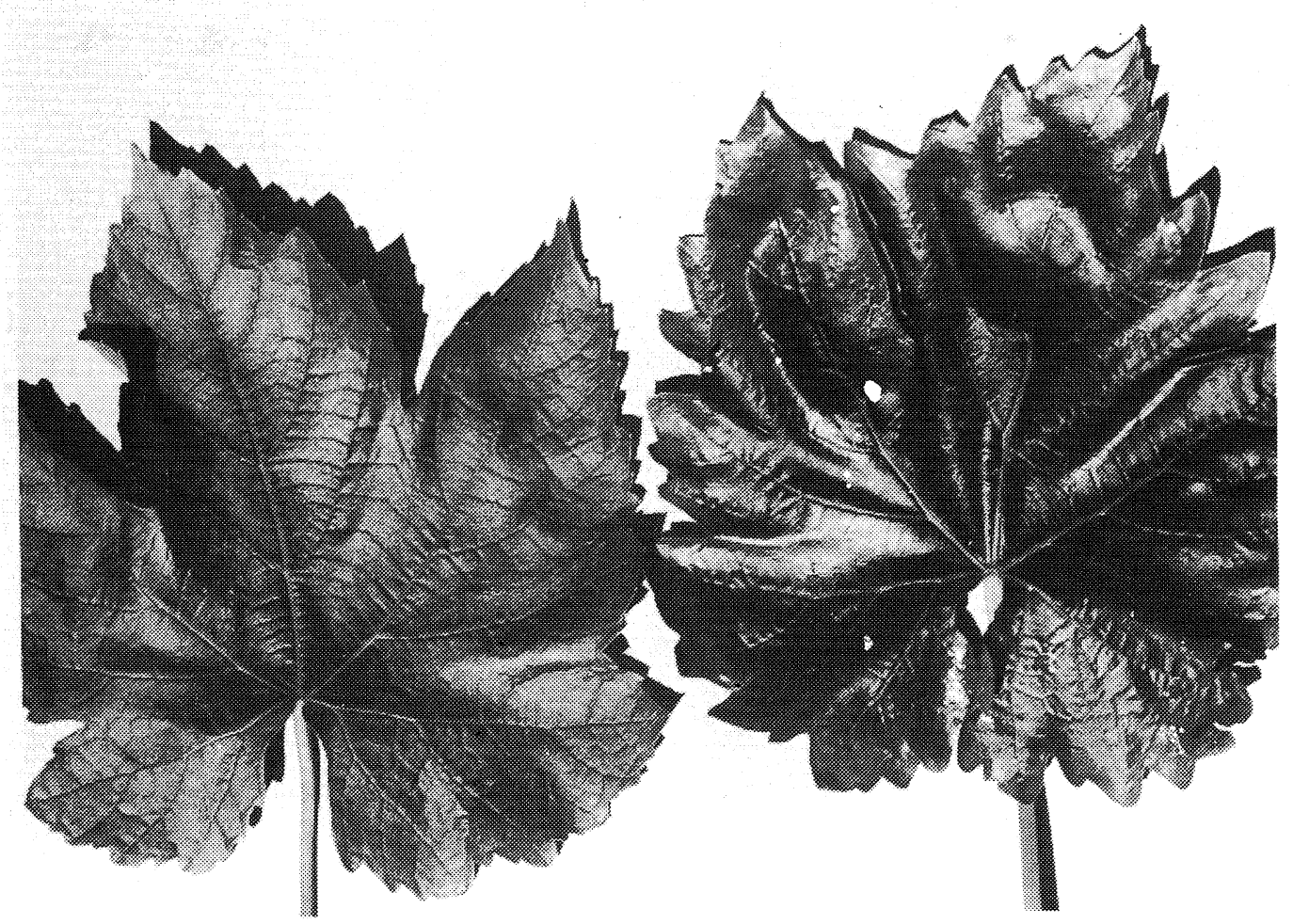

PLATE 3

Slight marginal yellowing of leaf (right), resembling $\mathrm{K}$ deficiency, but also having a general darker green colour and bulging appearance compared to a normal leaf (left). 
TABLE 8

Nutrient content of leaves and peduncles from normal Sultana vines and vines showing GAP, curled leaf and marginal yellowing symptoms - Lower Orange River region, October 1979

\begin{tabular}{|c|c|c|c|c|c|c|c|c|c|c|c|}
\hline \multirow{2}{*}{$\begin{array}{l}\text { Plant } \\
\text { material }\end{array}$} & \multirow{2}{*}{$\begin{array}{l}\text { Diagnosis/ } \\
\text { source }\end{array}$} & \multicolumn{10}{|c|}{ Element } \\
\hline & & $\begin{array}{l}\mathrm{N} \\
(\%)\end{array}$ & $\begin{array}{l}\mathrm{P} \\
(\%)\end{array}$ & $\begin{array}{l}\mathrm{K} \\
(\%)\end{array}$ & $\begin{array}{l}\mathrm{Na} \\
(\%)\end{array}$ & $\begin{array}{l}\mathrm{Ca} \\
(\%)\end{array}$ & $\begin{array}{l}\mathrm{Mg} \\
(\%)\end{array}$ & $\begin{array}{l}\mathrm{Mn} \\
(\mathrm{ppm})\end{array}$ & $\begin{array}{l}\mathrm{Zn} \\
(\mathrm{ppm})\end{array}$ & $\begin{array}{l}\mathrm{Fe} \\
(\mathrm{ppm})\end{array}$ & $\begin{array}{l}\mathrm{Cu} \\
(\mathrm{ppm})\end{array}$ \\
\hline \multirow{4}{*}{ Leaf blade } & Doubtful 1), shiny spot & 3,54 & 0,29 & 1,00 & 0,01 & 1,55 & 0,29 & 127 & 25 & 248 & 11 \\
\hline & Shiny spot & 3,92 & 0,33 & 0,64 & 0,01 & 1,82 & 0,41 & 172 & 48 & 238 & 16 \\
\hline & Curled leaf & 3,81 & 0,32 & 0,71 & 0,02 & 1,29 & 0,28 & 115 & 27 & 269 & 16 \\
\hline & Marginal yellowing & 3,81 & 0,34 & 0,58 & 0,01 & 1,62 & 0,29 & 157 & 40 & 213 & 16 \\
\hline \multirow[t]{5}{*}{ Petiole } & Normal & 1,11 & 0,43 & 1,58 & 0,18 & 0,60 & 0,40 & 25 & 26 & 59 & 9 \\
\hline & Doubtful 1), shiny spot & 1,18 & 0,31 & 1,38 & 0,08 & 0,82 & 0,45 & 49 & 32 & 64 & 11 \\
\hline & Shiny spot & 2,10 & 0,38 & 0,78 & 0,07 & 1,05 & 0,74 & 80 & 86 & 64 & 10 \\
\hline & Curled leaf & 1,53 & 0,47 & 1,15 & 0,20 & 0,76 & 0,47 & 69 & 86 & 67 & 11 \\
\hline & Marginal yellowing & 1,79 & 0,37 & 0,87 & 0,07 & 0,99 & 0,63 & 128 & 33 & 158 & 12 \\
\hline \multirow[t]{3}{*}{ Flower cluster } & Normal & 3,15 & 0,45 & 2,07 & 0,002 & 0,36 & 0,18 & 34 & 32 & 159 & 25 \\
\hline & Doubtful 1), black bunch & 3,42 & 0,38 & 1,45 & 0,016 & 0,32 & 0,19 & 48 & 30 & 151 & 22 \\
\hline & Black bunch & 3,38 & 0,41 & 1,53 & 0,020 & 0,35 & 0,20 & 51 & 31 & 148 & 22 \\
\hline \multirow{3}{*}{$\begin{array}{l}\text { Leaf blade } \\
\text { tissue }{ }^{2)}\end{array}$} & Normal & 3,47 & 0,30 & 0,93 & 0,02 & 1,10 & 0,28 & 83 & 55 & 404 & 48 \\
\hline & Adjacent to shiny spot & 3,85 & 0,32 & 0,80 & 0,01 & 2,06 & 0,41 & 198 & 84 & 334 & 64 \\
\hline & Shiny spot & 3,84 & 0,34 & 0,76 & 0,01 & 1,86 & 0,36 & 193 & 157 & 312 & 117 \\
\hline \multirow{4}{*}{$\begin{array}{l}\text { Peduncle } \\
\text { tissue }\end{array}$} & Normal & 3,96 & 0,55 & 2,10 & 0,110 & 0,35 & 0,14 & 20 & 26 & 254 & 25 \\
\hline & Doubtful 1), black bunch & 5,46 & 0,48 & 0,86 & 0,005 & 0,44 & 0,32 & 39 & 28 & 314 & 22 \\
\hline & Adjacent to black girdle & 4,94 & 0,42 & 0,98 & 0,044 & 0,34 & 0,25 & 56 & 159 & 760 & 320 \\
\hline & Black girdle & 5,86 & 0,46 & 0,63 & 0,049 & 0,64 & 0,33 & 68 & 62 & 567 & 70 \\
\hline
\end{tabular}

1) Leaf blade, petiole and peduncle material showing no symptoms but sampled from GAP vines.

2) Leaf blade tissue was sampled by means of a cork drill in order to isolate shiny spot and normal appearing tissue.

Leaves wtth shiny spot and marginal yellowing symptoms were characterised by a low $\mathrm{K}$ content in the petioles and a high $\mathrm{Ca}$ and $\mathrm{Mn}$ content of both leaf blades and petioles, whereas the nutrient content of curled leaf tissue did not differ convincingly from that of normal leaves, except for a tendency towards a higher $\mathrm{N}$ content in blades and petioles and a lower $\mathrm{K}$ content in petioles of curled leaves. According to Conradie (1981) the $\mathrm{N}$ content of petioles of Chenin blanc vines grown in sand culture is $1,4 \%$ during flowering, and that of leaf blades $3,6 \%$, indicating that the Sultana vines concerned enjoyed luxurious $\mathrm{N}$ nutrition conditions. The high $\mathrm{N}$ nutrition apparently gives rise to various abnormal symptoms like shiny spot, curled leaves and black bunches, as well as to symptoms resembling the classical K-deficiency symptom (Plate 3 ). The reason for the associated high $\mathrm{Mn}$ concentrations is not yet understood. The shiny spot symptom seems similar to the glossy patches attributed to early season $\mathrm{N}$ build-up symptoms described by Christensen, Kasimatis \& Jensen, (1978). De la Harpe \& Archer (1981) found these spots to be collapsed epidermal cells showing cross wall development in pallisade tissue, plasmolyses and other abnormalities, and attributed it to possible heat and moisture stress.

Leaf curl is considered part of $\mathrm{K}$ deficiency symptoms in Sultana (Woodham \& Alexander, 1970), associated with rapidly expanding young leaves. Locally, $\mathrm{K}$ deficiency was found to induce leaf curl on the basal leaves of Chenin blanc, but was accompanied by the classical marginal scorch of K-deficiency. Symptoms resembling this were encountered amongst the Sultana of the Lower Orange River region, but were not associated with GAP. The eventual vigorous growth due to a high $\mathrm{N}$ supply and hot climate, results in large, thin basal leaves, and may lead to induced $\mathrm{K}$ deficiency symptoms (Champagnol, 1971; 1978).

Investigations by Kliewer (1978) also showed GAP vines to have very high concentrations of $\mathrm{N}$ and arginine in the petioles. Apparently GAP is similar to the situation found in California on Sultana and Grenache vines which overbear and continue to grow after harvest due to irrigation, with resulting low carbohydrate reserves and low frost resistance (M. Kliewer, 1978 - personal communication). Young vines which die back to ground level during winter, but again develop vigorous shoots from the still living subterranean parts, are also a wellknown phenomenon in the Lower Orange River region.

From Table 8 , a very pronounced tendency towards $\mathrm{N}$ build-up in shiny spots and especially in black peduncle tissue, with a corresponding drop in $\mathrm{K}$ content, is evident when compared to normal tissue. This may be related to the findings of Calo, Costacurta \& Cancellier (1979), that excessive $\mathrm{N}$ can cause flower abortion.

Contrary to the results of Terblanche (1974), no evidence of high $\mathrm{Na}$ concentrations could be found. Judging from the preliminary survey results (Saayman, 1983), Na appears to enhance GAP. The vines studied by Terblanche (1974) were probably affected by high $\mathrm{Na}$ concentrations in the soil and accumulated high concentrations of $\mathrm{Na}$ in an effort to compensate for the low $\mathrm{K}$ content of affected plant material (Table 7), possibly caused by luxurious $\mathrm{N}$ nutrition and the presumably slow $\mathrm{K}$ releasing characteristics of the soils involved.

High Mn concentrations were again associated with high $\mathrm{N}$ contents of plant tissue (Table 8 ). Shiny spots also showed a high Ca content, whereas the black bunch tissue contained high concentrations of $\mathrm{Zn}, \mathrm{Fe}$ and $\mathrm{Cu}$. The reason for this is unknown. 


\section{CONCLUSIONS}

Although an apparent $\mathrm{K}$ deficiency seems to be associated with GAP afflicted vines, GAP does not convincingly resemble classical K-deficiency symptoms, and $\mathrm{K}$ fertilisation alone cannot alleviate the problem. Therefore, the low $\mathrm{K}$ content of plant material does not appear to be the primary cause of GAP. Excessive $\mathrm{N}$ uptake, accompanied by low $\mathrm{K}$, high $\mathrm{Mn}$ and sometimes high $\mathrm{Na}$ and $\mathrm{Mg}$ concentrations, appear to be characteristic of GAP afflicted plant organs.

Shiny spot and curled leaf symptoms seem to be related to vigorous growth, high $\mathrm{N}$ and low $\mathrm{K}$ contents of plant organs. Marginal yellowing, resembling potassium deficiency and eventual scorching of basal leaves which are sometimes encountered, is not necessarily associated with GAP, but also appears to be induced by excessive $\mathrm{N}$ nutrition. Although indications of a higher $\mathrm{N}$ supply in the case of GAP soils were obtained, some unexplained relationships between the humus in the soil and the $\mathrm{N}$ supply remain to be investigated.

Sodium, at times present in toxic concentrations, seems to be involved in black bunch and shiny spot symptoms, but the presence of high $\mathrm{N}$ concentrations in GAP affected plants were a more consistent factor and are apparently the primary cause of black bunch symptoms and flower cluster abortion. Luxurious $\mathrm{N}$ nutrition also seems to be indirectly responsible for flower shatter. The significance of the high Mn concentrations appears to be related to high $\mathrm{N}$ values in the plant material, but the mechanism of the high $\mathrm{N}$ concentrations and shiny spots, black bunches and flower cluster abortion relationships, requires further study.

There is little doubt that one of the factors causing GAP is the abnormal growing pattern of the Sultana vines in this region. This is caused by climatic conditions and the fertile soil, which stimulate continued vigorous shoot growth after harvest until the first frost in winter kills the leaves, thus inhibiting the translocation of carbohydrate reserves, as has been shown experimentally. The lack of reserves makes young vines susceptible to frost damage and older vines prone to uneven budding and unable to support new shoot growth, leading to the abortion of young flower clusters. Climatic conditions clearly enhance or alleviate this faulty carbohydrate/N nutrition problem, but the mechanism by which this is caused requires further investigation.
The apparently insufficient irrigation during dormancy which enhanced GAP, as was found during the survey as well as in practice, probably caused more pronounced fluctuations in soil temperatures because of the dry soil. Unfavourable temperatures may affect hormone balances and root activity negatively.

In view of the indications obtained, future research should be aimed at testing the hypothesis of excessive $\mathrm{N}$ nutrition being the major cause of GAP, and at studying the effect of $\mathrm{N}$ and temperature on the physiology of the vine, as well as finding practical solutions for the excessive vigour and abnormal growth cycle of Sultana in the hot and fertile conditions of the Lower Orange River or similar environments.

\section{LITERATURE CITED}

AGENBACH, W. A., 1975. Mikrobiologiese aspekte van die Laer Oranjerivier-winderdgronde, met spesiale verwysing na die Groeistilstandsiekteverskynsel. M.Sc. (Natuurwetenskappe) Verhandeling, Univ. Stellenbosch, 7600.

CALO, A., COSTACURTA, A. \& CANCELlIER, S., 1979. Influence du climat et des conditions du nutrition sur la fécondation et la nouaison des fleurs. Bull. Off. int. Vin 52 (585), 903-914.

CHAMPAGNOL, F., 1971. Étude des quelques effets de la fertilisation azotée sur la vigne. Extrait du Progrès agric. Vitic. 88 (9-21), $1-57$.

CHAMPAGNOL, F., 1978. Fertilisation optimale de la vigne. Progrès agric. Vitic. 95 (15 et 16), 423-440.

CHAMPAGNOL, F., 1980. La matiére organique des sols du Midi de la France. Progrès agric. Vitic. 97(8), 161-173.

CHRISTENSEN, L. P., KASIMATIS, A. N. \& JENSEN, F. L. 1978. Grapevine nutrition and fertilization in the San Joaquin Valley. Agric. Sci. Publications, Univ. Calif., Berkeley.

CONRADIE, W. J., 1981. Nutrient consumption by Chenin blanc grown in sand culture and seasonal changes in chemical composition of leaf blades and petioles. S. Afr. J. Enol. Vitic. 2(1), 15-18.

DE LA HARPE, A. C. \& ARCHER, E., 1981. Effect of Growth Arrestment Disease on the anatomy and ultrastructure of Vitis vinifera L. var. Sultana. S. Afr. J. Enol. Vitic. 2(2), 51-59.

FOX, R. H. \& PIEKIELEK, W. P., 1978. Field testing of several nitrogen availability indexes. Soil Sci. Soc. Am. J. 42, 747-750.

KLIEWER, W. M., 1978. Final report of work completed during research fellowship, August 26, 1977 to March 12, 1978. Unpublished report, VORI, Stellenbosch, 7600.

SAAYMAN, D., 1983. Investigations into the causes and control of the Growth Arrestment Phenomenon of Sultana. I. Symptoms and survey results. S. Afr. J. Enol. Vitic. 4(1), 21-26.

TERBLANCHE, J. H., 1974. Besoek aan Upington gebied in verband met Groeistilstandsiekte (24-26/10/73). Unpublished report, VORI, Stellenbosch, 7600.

WOODHAM, R. C. \& ALEXANDER, D.McE., 1970. Foliar symptoms of malnutrition in the Sultana vine. Div. Hort. Res. Technical paper No. 1. CSIRO, Australia. 